\title{
NEW PRIVATE MEDIA IN FRENCH-SPEAKING WEST AFRICAN COUNTRIES : PROBLEMS AND PROSPECTS
}

\author{
The Cases of Benin and Niger
}

\section{FRERE Marie-Soleil}

Department of Communication, Information and Journalism

Université Libre de Bruxelles

CP 123

50, Avenue Franklin Roosevelt

1050 Bruxelles

Belgium

\section{SUMMARY}

In this paper, we will try to take a closer look at the rise of the democratic transition in two French-speaking West African countries: Benin, often referred to as "the country where it all started", and Niger that can be considered as one of the weak copies of the Beninese model. In the first part of the paper, we will try to show how the democratic experiment took place in both countries and how private and government-owned media came to play an active role in all main political changes. In the second part, we will take a closer look at the role of the new private written press in the democratic transition and try to mention the main problems facing both the press and the democracy implementation. Eventually, we will mention the recent political events that occurred in Benin and Niger, showing that the democratic process has generated very different outcomes.

KEY WORDS: Africa, Benin, Niger, democracy, press, mass-media, democratic transition 


\section{Introduction}

In 1989, on the eve of what has been called "the African spring", the media in the French-speaking countries of West Africa were totally underdeveloped and government-controlled. Except for Senegal, which has always had a particular status and history, all countries were under authoritarian civil or military rule and the freedom of the press, even if mentioned in the Constitutions or fundamental texts, did not have any real existence. The media were supposed to serve "national integration" and "development" but were in fact devoted to the praise of the political leaders or the one-party system.

The underdevelopment of those media was not only the consequence of dictatorship but could be traced back to colonial times. In fact, France has always had a very oppressive attitude towards African-owned press in its colonies, while the British were much more open to local press (Ziegler and Asante, 1992). That is one of the main reasons why the first newspaper controlled by Africans in French Africa only appeared in 1920 in Dahomey (currently Benin) ${ }^{1}$, more than a century after the first "indigenous" newspapers in English. ${ }^{2}$

In 1960, when the West African French Territories reached Independence ${ }^{3}$, only two of them, Senegal and Ivory Coast, had a daily, owned by a French businessman. The new governments quickly evolved towards authoritarian regimes, persecuting the opposition and private press until they disappeared or were forbidden. In the name of "nation building" and "development", they imposed state monopoly on all media and the wave of military coups in the early ' 70 s usually reinforced that tendency. But at the end of the ' 80 s, the "wind of democracy" reached Africa, private newspapers appeared and the media became active participants in most democratic transitions.

1. Other reasons can be found in the very low literacy rate and the weak economy in French Africa (Ainslie, 1966).

2. The first West African newspaper was created in Liberia in 1802. It was soon followed by publications in the British colonies of Sierre Leone, Nigeria and Gold Coast. In 1900, about 70 newspapers were edited in British West Africa and Liberia, most of it political and hold by Africans (Barton, 1979).

3. Only Guinea, which had voted "no" at the French referendum in 1958, following nationalist leader Sékou Touré, had become independent in 1958. 


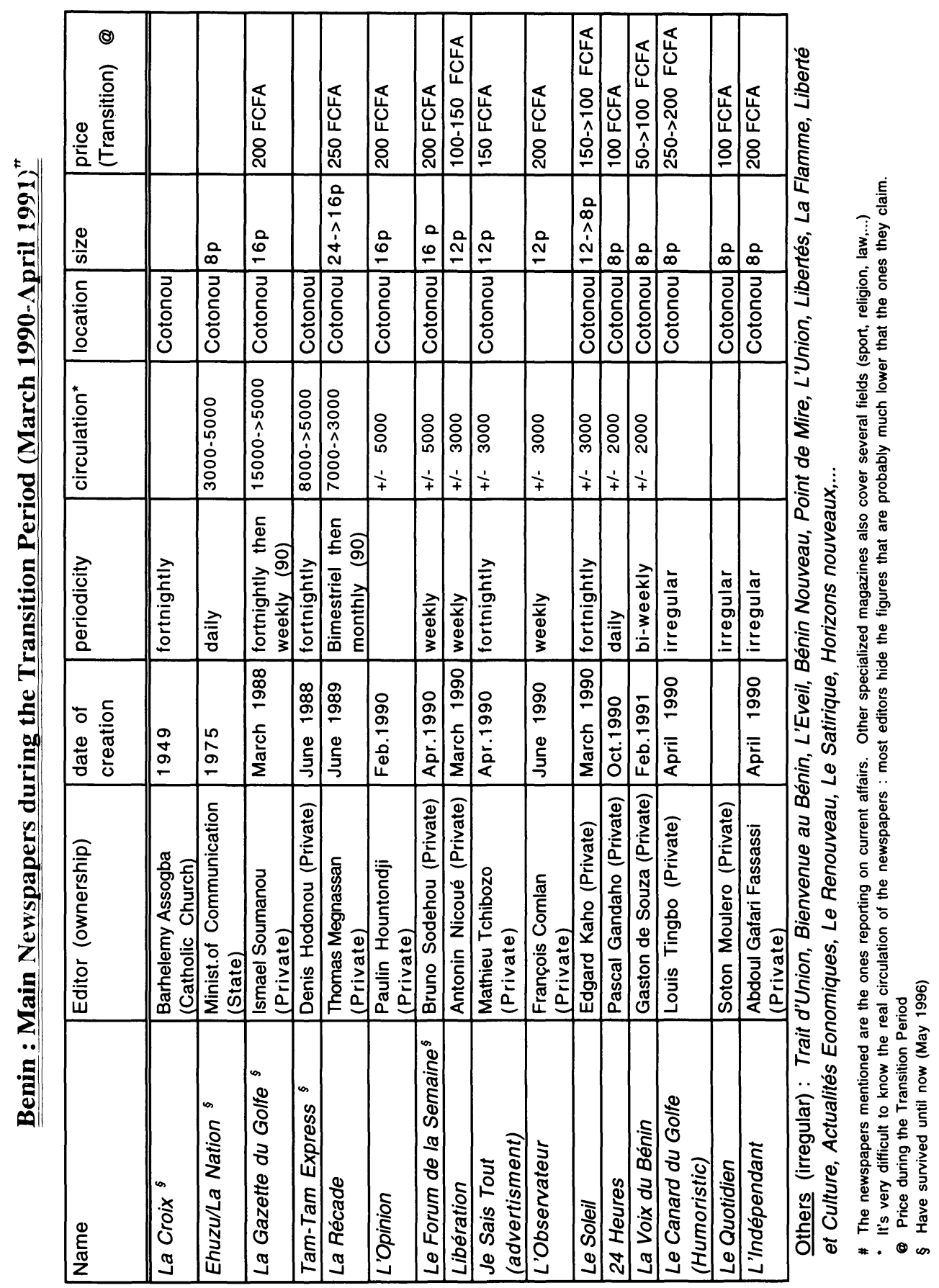




\section{The Democratic Transition in Benin}

In 1988, Benin was a ruined and exhausted country. The state was bankrupt and unable to pay the salaries of the too numerous civil servants ${ }^{4}$. The economy had collapsed: exports, mainly based on cotton and palm oil production, kept diminishing and $90 \%$ of all commercial transactions consisted of smuggling with neighbouring Nigeria (Allen, 1992). The main reasons for that disaster were to be found in several factors: the colonial legacy, the drop in prices of raw material and 16 years of a military marxist-leninist, widely corrupted, regime.

The media were restricted to one governmental newspaper, a daily called Ehuzu (which means "revolution") and one broadcasting national institution, the O.R.T.B. (Office de Radio Télévision du Bénin). Those media were only the mouthpieces of the government but by 1988 , their financial situation was so dramatic that they could hardly fulfill that official duty. There was also another newspaper, La Croix $d u$ Bénin, in the hands of the Catholic Church: it was probably tolerated because it was old (it was founded in 1949) and also because it didn't deal directly with political current affairs. There was no possibility in Benin for a dissident or critical voice to make itself heard, although the clandestine P.C.D. (Parti Communiste du Dahomey), "bête noire" of the regime, had been fighting in the dark. The PCD was editing a small-circulation clandestine paper, La Flamme, devoted to its hatred towards the regime of General Mathieu Kérékou: people who were found in possession of that newspaper or even just photocopies of it were immediately arrested and sent to jail ${ }^{5}$.

Such was the situation when, in March 1988, a private newspaper, La Gazette $d u$ Golfe, appeared, quickly followed, in June, by another one: Tam-Tam Express. At first, those newspapers were probably allowed by the government for two main reasons: on the one hand, students and civil servants were starting to demonstrate, demanding their scholarships and wages to be paid. Clandestine pamphlets against the government were distributed in most main cities. The Kérékou

4. In Benin, as in many African countries, civil service has always meant privilege as it offered regular salaries and other advantages. All graduated students would automatically become civil-servants. As a result, the civil service grew from 7.000 jobs in 1972 to 47.000 in 1989 (Heilbrunn, 1992).

5. Another group fighting the establishment was the one of the University students. Several times $(1977,1985)$, demonstrations took place on the campus, often ending in riots with the police and jail sentences for the leaders of the student movements. 
regime probably thought that allowing the publishing of a private newspaper could be a means to soothe civil unrest. Newspapers were controlled by a board of censors which only allowed publication so they could play the part of the safety valve. On the other hand, the existence of a private press was a way of pleasing foreign partners whose support was becoming increasingly necessary for the Beninese state's survival.

For one of the two newspapers, there was probably a third motivation. Whereas La Gazette du Golfe was mainly devoted to describing social problems and the shared misery of the people (without direct criticism of the authorities), Tam-Tam Express almost exclusively paid attention to the failures of the banking system. The paper made revealed how a few privileged people of the regime reaped huge financial profits by transferring money from the Beninese national banks to private accounts in Europe (Vittin, 1991). By denouncing the transfers and naming the people involved in that nationwide theft, Tam-Tam Express probably helped Kérékou to sully the reputation of the collaborators he wanted to get rid of. This newspaper was thus probably a means for the regime to sort out its own inner quarrels.

Nevertheless, these two newspapers, even if they were meant by the country leaders to serve as their tools, soon escaped from that control. In fact, the popular unrest kept growing (Gbado, 1992). The collapsing of the banking system, soon leading to the closure of all private accounts, prevented the civil servants from having access to their savings. The absence of salaries thus became a much bigger issue and, from January 1989, strikes and demonstrations multiplied. In June, the State was forced to sign a Structural Adjustment Agreement with the IMF in order to get a minimal funding to be able to pay a part of the salaries. But the counterpart demands of the IMF (staff cuts in the administration, less scholarship grants for students) would just make the popular dissent grow.

Meanwhile, events abroad, especially in Eastern Europe, had helped to change the tone of the popular claim. From economics, the demands grew to politics, including democracy, multi-partyism, and respect of human rights. Eventually, in December, President Kérékou was forced to announce the end of the marxistleninist ideology and the separation of the Party (the Parti Populaire de la Révolution Béninoise, PRPB) and the State. He also promised to organise a national Conference where all "the vivid forces of the nation" would gather and discuss the national issues (Ehuzu $\mathrm{n}^{\circ}$ 3596). By that time, the "media scenery" had profoundly changed in the country. Other private newspapers had appeared, voicing the grievances of the people and strongly criticizing the regime, and the official media we restarting to broaden their views. On December 11, the national television broadcasted images of a demonstration where Kérékou, who had gone down in the street in order 

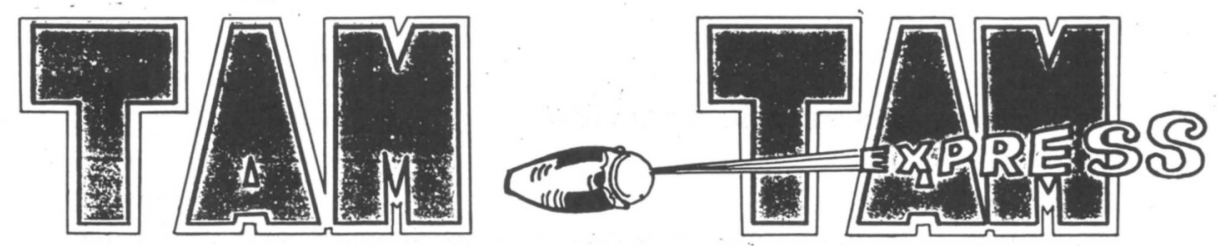

BIMENSUEL INDEPENDANT PARAISSANT A COTONOU N 88 DU 27 AVRIL AU 10 MAI 1992 Bénin 200FCFA - Afr.Occ. 250FCFA - France 6FF

\section{EHAS \\ ROSINE SOGLO CREE SON PARTI}

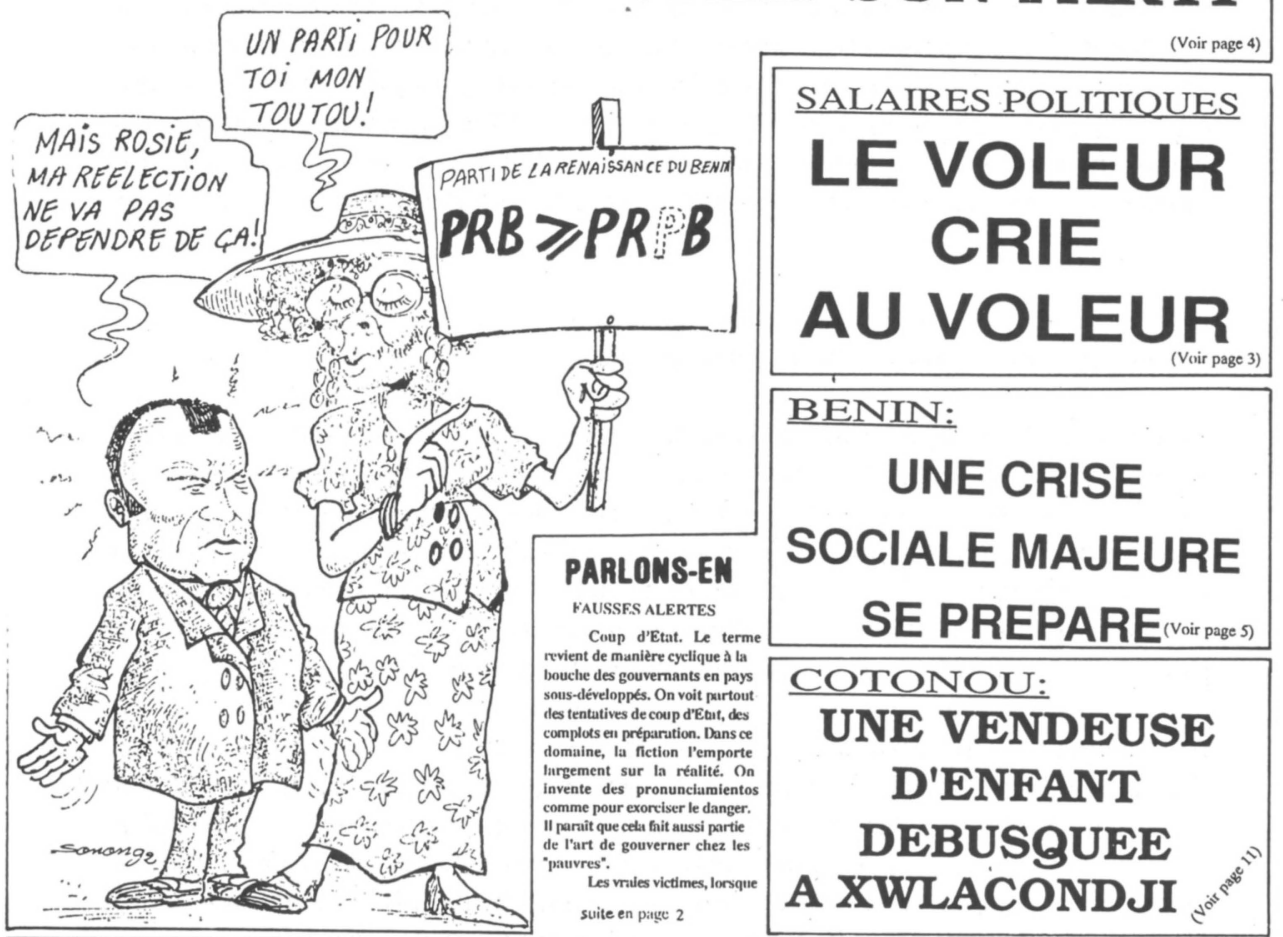

FAPPRENTISSAGEAUBENIN:

TOGO:

IL FAUT SAUVER L'UNITE NATIONALE 
to calm the unrest, was greeted with stones and insults. Obviously, things were changing in Benin...

\section{- The National Conference in Benin and the Transition period}

The National Conference eventually took place in Cotonou between February 19th and 28th 1990. 493 delegates chosen from political "groups" (there were no political parties yet), trade-unions, belonging to different religious backgrounds, professional associations, NGO's, governmental institutions, members of the diaspora... gathered during 10 very tense days (Raynal, 1991) ${ }^{6}$. Many times, the forum was about to fail under the weight of huge disagreements and the constant threats of the old PRPB dignitaries wanting to put an end to the Conference.

But the members eventually reached a consensus which was, very surprisingly, accepted by President Kérékou. The Conference decided to elect a new Prime Minister which would form and lead a transition government during 12 months. During this period, a new Constitution would be written and adopted by referendum, economic reforms would start and all the workers would go back to work and have their grievances settled. At the end of that transition period, free and fair elections would be held in order to designate a new President and a legislative body, the National Assembly (Adamon, 1995).

The National Conference of Benin was an important event, not only for the country but probably for French-Speaking West Africa as a whole, where similar grievances for more freedom and political participation were voiced, mainly in the capital cities (Eboussi-Boulaga, 1993). It was also an important turning-point, a real revolution, in the world of the media. The Beninese media actually showed that the written press, radio and television could turn their backs to manipulated (supposedly "development"or "revolutionary") journalism and be the tools needed to enforce a democratic process.

The private press helped to prepare the ground for the National Conference by paying much attention to all issues that should be discussed, interviewing political opponents, voicing the people's fears and concerns. During the Conference, all

6. Raynal (1991) shows how these delegates, calling themselves "representatives of the nation" actually belonged to very specific groups, mostly urban and intellectual. The uneducated peasantry, which is absolutely majoritary in Benin, was completely underrepresented. 
debates were broadcasted life by the radio, so that they could be followed even in the farthest villages. The television was not allowed to do the same but journalists made consistent efforts to overcome that limit and broadcasted images of the Conference and interviews of the delegates. All the debates were filmed and videotapes of the extended meeting were available all over Cotonou. At the end of the Conference, a special mention was granted to the journalists "considering that the involvement of the national press in its information task had been a powerful support and had played a decisive part in the success of the Conference" (Ehuzu). The delegates finally insisted on the fact that "the renewal of the media should lay the foundations of the Democratic Renewal." (Assevi, 1993)

The transition period, which lasted until April 1991, was probably the time when the Beninese press enjoyed the widest freedom of all its history. The private press grew: about fifty different newspapers were created, even if most of them were short-lived (L'Opinion, Le Forum de la Semaine, L'Observateur, Le Soleil...). They imposed a new conception of journalism with opinions, comments and political analysis. That press was free of all taboos and could sharply criticize the former regime as well as the government of new Prime Minister Nicéphore Soglo. It has played a decisive part during the constitutional referendum (commenting the projects, giving advice to the voters) as well as while the parliamentary and presidential elections (explaining the rules of the new pluralist political game, pointing out the practical problems). The press was at the same time a spectator and an actor of the democratic transition, just as it was both a cause and a consequence of the process.

Government-owned media also changed their tune. Ehuzu, the government newspaper, changed its name into La Nation ("The Nation"): the marxist-leninist revolution was definitely over. Most of its journalists were involved in private newspapers where they could earn more money and reveal the writing abilities they had been hiding for years behind the traditional political cant. In the ORTB, the change was obvious as well. The name of the radio was changed from "The Voice of the Revolution" to "Radio Cotonou". The station opened its doors and microphones to different political parties and social forces. New shows were created, based on public debates and confrontation between people with different opinions. The television station went through similar changes, even though they were slower and maybe not as deep.

The attitude of the people towards the media also changed. The private press was of course very popular, and the surprise was more on the side of the government-owned media. For years, the people had despised the national media and turned to international broadcasting (Quenum, 1991). If it was not for the 


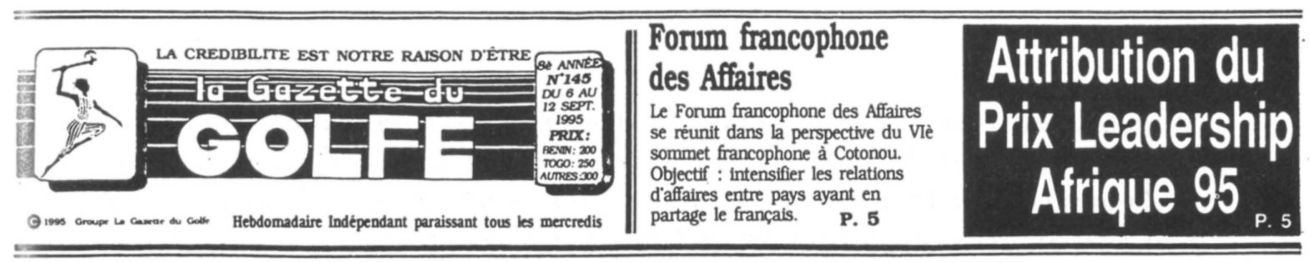

\begin{tabular}{|c|}
\hline 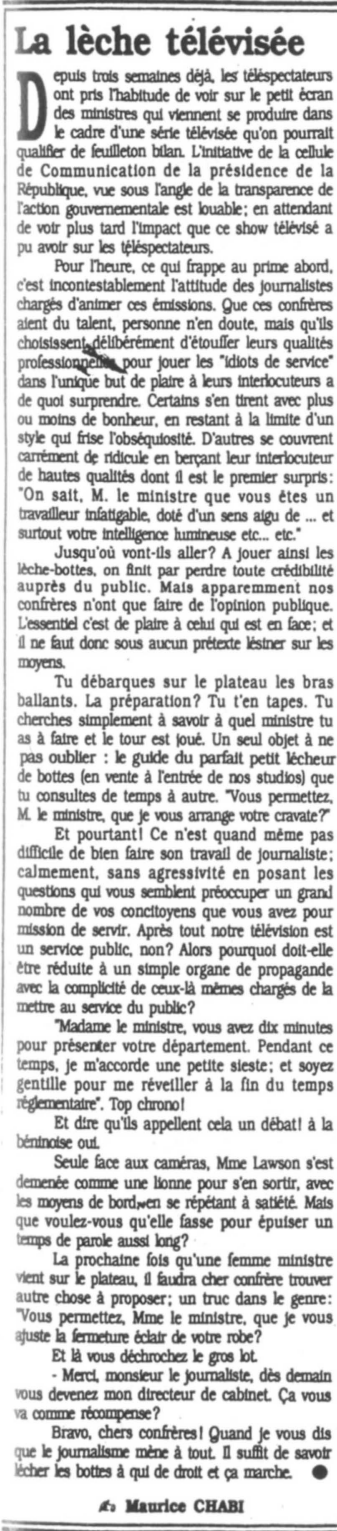 \\
\hline
\end{tabular}

\section{NOMADISME POLITIQUE:}
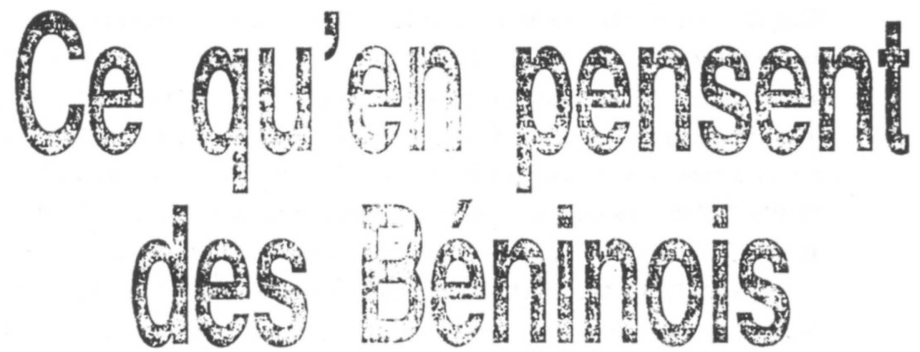

La transhumance n'est pas un phénomène nouveau sur l'échiquier politique béninois. Mais depuis quelques mois, il tend à se généraliser, telle une gangrène en train de vicier la vie nationale. La Gazette du Golfe donne ici la parole à certains concitoyens. Leurs réactions prouvent, si besoin en était encore, que les Béninois ne sont pas indifférents aux comportements des politiques. $\quad$ PP. $3 \& 4$

\section{VOUS AVEZ DIT "VENTROCRATLE"?}

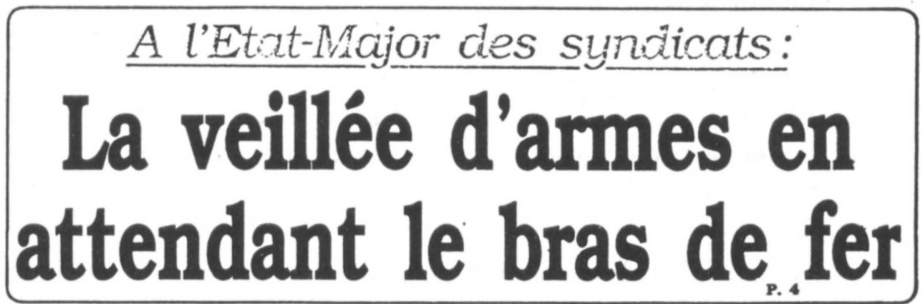

Vle Sommet de la Francophonie: QUE CACHE LA VISTE DU PRESDENT SOGLO SUR LES CHANTIERS? $\quad$ :.

\section{DANS CE NUMÉRO:}

Un supplément de 12 pages réalisé par des journalistes du Burkina Faso du Niger, du Togo, de la Guinée, de la Côte d'lvoire et du Bénin sur le thème "Causes et incidences environnementales des mouvements de la population en Afrique Occidentale côtière" 
obligation for all public places (bars, restaurants, administrations...) to be on the national channel "La Voix de la Révolution", there would have been no listeners or viewers of the ORTB for more than a decade. But, as "Radio Cotonou" went through that dramatic change, the audience came to appreciate it again. During the National Conference, transistors sellers ran out of stock as everybody in Cotonou was walking around with his radio receiver sticked on his ear.

The attitude of the new government towards the media was at first totally different from the one under the PRPB regime. There was no board of censors commission anymore and the newspapers did not have to get a permit before publishing. The transition legislative body, the Haut Conseil de la République (HCR) and the government became used to meet the press and organise press conferences. Nevertheless, this is probably the point where the new problems first arose. Because, as the Soglo government came progressively to meet sharp criticism (which was unavoidable because the situation of the country was so terrible that all problems could not get a quick solution), the executive body tried more and more to influence and control the national media (Quenum, 1991).

\section{- The post-transition period}

At the end of the transition period, in March 1991, Nicéphore Soglo won the electoral battle against Mathieu Kérékou and became President of the Republic of Benin. If the so-called transition period was over, the country was nevertheless still in the process of implementing democracy. Democracy not only means having a Constitution and democratic institutions, it also means a "political culture" and a general state of mind, among the leaders as well as among the people in general. Benin and the Beninese media are thus still going through the transition.

Most of the private newspapers of the transition period have quickly disappeared. The ones that survived (La Gazette du Golfe, Tam-Tam Express, Le Forum de la Semaine...) probably succeeded because of the following reasons: most of them were in the hands of business men or rich people giving them strong financial backing, they all tried since the very beginning to respect the periodicity and most of them recruited some good professional journalists, avoiding to rest only on the goodwill of amateurs.

The Beninese private press is facing some important difficulties (lack of financial means, low literacy rate among the population) and has let dangerous deviations occur (constant "sensationalism" of some media, tendency to corruption). We 
will see in the third part of this paper how the problems of the press and those of the democratic process itself are related.

Currently, Benin is at a turning point of its democratic process. On March 18th 1996, six years after the Beninese National Conference, presidential elections were held and won by the former military leader Mathieu Kérékou? the electoral campaign, new private newspapers appeared, backing the different candidates but they disappeared rapidly after the election. The attitude of the national media during the whole process showed how much the Soglo administration had succeeded in gradually imposing its control on the radio and the television stations. The attitude of the new regime towards the press has so far been respectful. But the new press law, that was proposed during the transition period to replace the outdated law of 1960, has not yet been presented in front of the National Assembly. It seems that President Kérékou is not more in a hurry than was former President Soglo to give the private press a new and appropriate legal framework.

7. Nicéphore Soglo emerged in the lead at the first round with $35,64 \%$ of the votes followed by Kerékou who won $33,94 \%$. But after most of the other candidates rallied to Kérékou, the former military leader became favourite for the second round which he ended up winning with $52,49 \%$ of the votes. Soglo had lost much popularity because of the structural adjustment policy he implemented (leading to a spectacular economic recovery but very painful for the many public sector workers) and of his growing authoritarianism, nepotism and favoritism. 


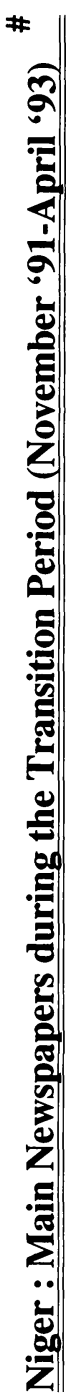

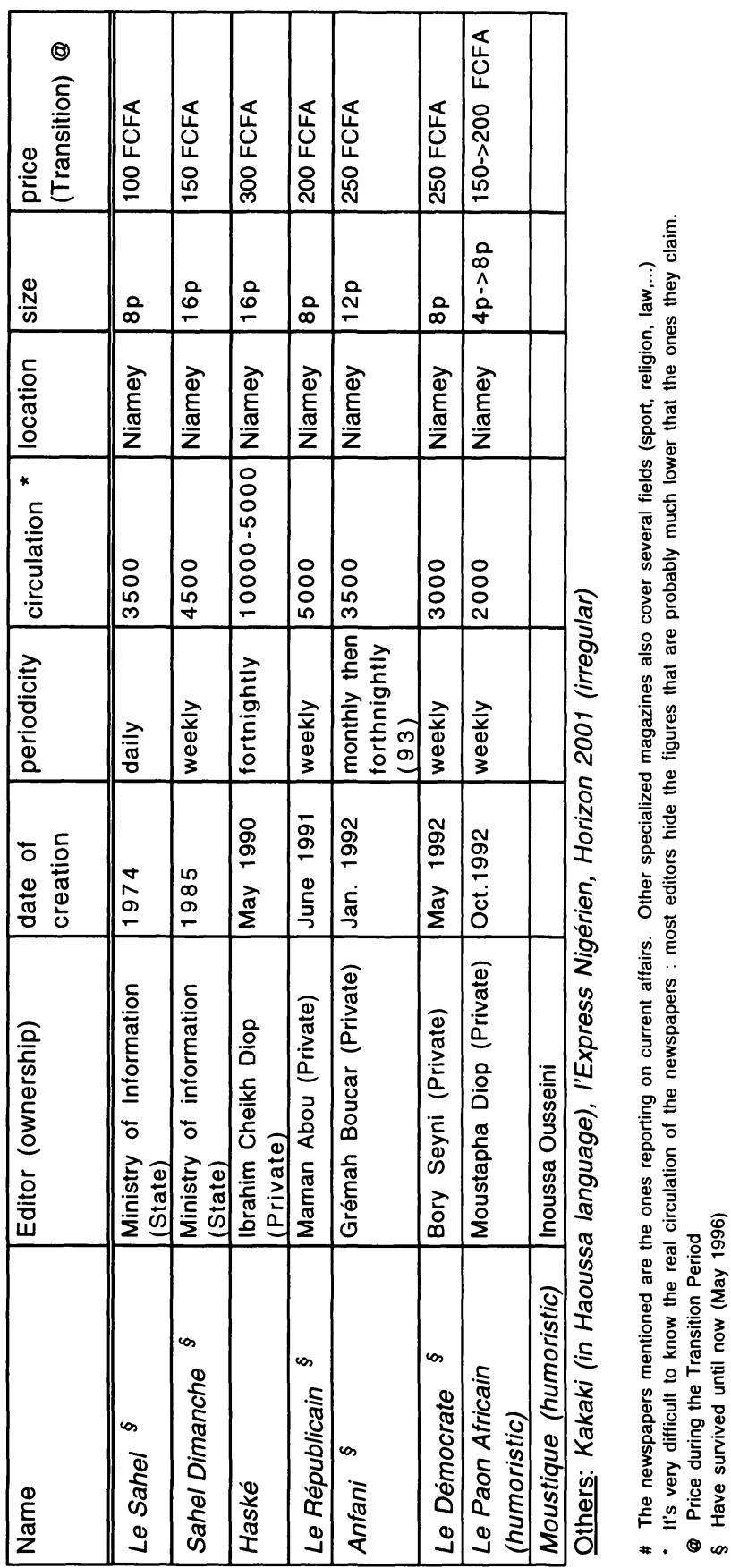




\section{Democratic Transition in Niger}

Niger, as Benin and many West African countries during the '80s, has lived for many years under the rule of a strong military dictatorship. In 1987, after the death of the severe President Seyni Kountché, the moderate General Ali Saibou came to power, filling Nigeriens with hope. The new President started to engage the country on the path of political reforms, even though the changes were only "limited" and "locked" (Raynal, 1991). The military partially drew back from the stage, as a new Constitution established a civil one-party system in 1989. But the expectations of the Nigerien people were much higher and unrest started on the University campus and among the civil servants. In Niger too the state was in an uncomfortable situation: a poor, desertic, landlocked country, Niger had survived for years thanks to its uranium production. But the decline of the price of uranium on the international market and the widely extended corruption among the ruling elite quickly put the country into a difficult position. In 1984, Niger started to follow a Structural Adjustment Program but most of the requirements of the IMF were quite unpopular, especially among the urban and educated middle-class ${ }^{8}$.

The discontent did not have any channel to express their concern as all media were government-owned and strictly controlled. The national daily, Le Sahel, and the weekly, Le Sahel Dimanche, were under the direction of the Ministry of Information. Most of the journalists had defected either to create private businesses, either to leave the country for any place where they would be able to write freely. There had been a few attempts by those defecting journalists to set up independent newspapers, dealing with economics (L'Opérateur Economique), sports (Promo-Sport) or religion (the islamic review IQRA), but none of them lasted long and none of them wrote about political or social problems. Besides, the national broadcasting institution, l'O.R.T.N. (Office National de Radio Télévision du Niger), including the radio station "La Voix du Sahel" and a new television station operating only since 1988 , was merely the official mouthpiece of the political leaders and a tool for propaganda.

There were no reports in those official media about the demonstrations and strikes shaking the Nigerien regime and growing constantly. Even more so when two tragic incidents intensified the popular claim for democracy and provoked

8. For years, in Niger as in Benin, it had been established that all students who graduated would automatically find a job in the civil service. That's why the IMF requirement of reducing the number of civil servants was ill accepted by both students and civil servants. 
international disapproval. On February 9th 1990, a few days before the opening of the National Conference in Benin, the police charged at a group of unarmed students peacefully demonstrating, killing three and injuring more than sixty9. In La Gazette du Golfe in Cotonou, the headlines of the Nigerien correspondant read: "In Niger like in China: Police Shoots Students"10. The second tragedy took place in the north of the country where, in May, the army massacred about 70 members of the Tuareg community, wounding about a hundred others ${ }^{11}$.

Condemned by the international community, harrassed by inner grievances, the Nigerien regime had to reconsider its "limited and locked democratic opening". It did not have much choice, in front of the demands of the Bretton Woods Institution now imposing "political conditionnality" and the French decision (announced at the La Baule Summit in June 90) to link aid with the progress of democracy. Niger needed foreign money too much to allow itself to go against the donators'will. Slowly but inexorably, the government was forced into making concessions.

In May, a first private newspaper was allowed, Haské (which means "light"), which started immediately to voice popular claims. It was the first private political paper in Niger for 31 years, as freedom of the press had been stifled even before the country reached Independence. The Nigerien people were enthusiastic and captivated by that new astonishing style and content. The circulation rapidly grew to 15.000 copies which is enormous for a country where hardly $10 \%$ of the population can read French and where a newspaper costs more than a meal.

In November, multi-partyism was officially allowed and in December a National Conference was announced to be scheduled for May 91. For more than 7 months, the country lived in the expectation of the Conference (the administration and schooling system were paralysed) and in the awaiting of Haské editions. It remained the only private newspaper in the country for a whole year. The national daily Le Sahel, meeting huge financial problems, tried to survive but had to interrupt its publication from December 1989 to April 1991 and from June 1991 to February 1993. Le Sahel-Dimanche at least kept coming out regularly.

9. The Student Union talked about 10 people killed. The high number of victims is due to the fact that the students were on the narrow bridge crossing the Niger river when the police started to shoot. Running away was almost impossible.

10. La Gazetten du Golfe n43, February 16th-28th 1990.

11. Here again, the official toll is contested by international humanitarian organisations (estimating the deaths to 400), and the local Tuareg people (talking about one thousand). 
Il n'y a pas de démocratie sans liberté-d'expression

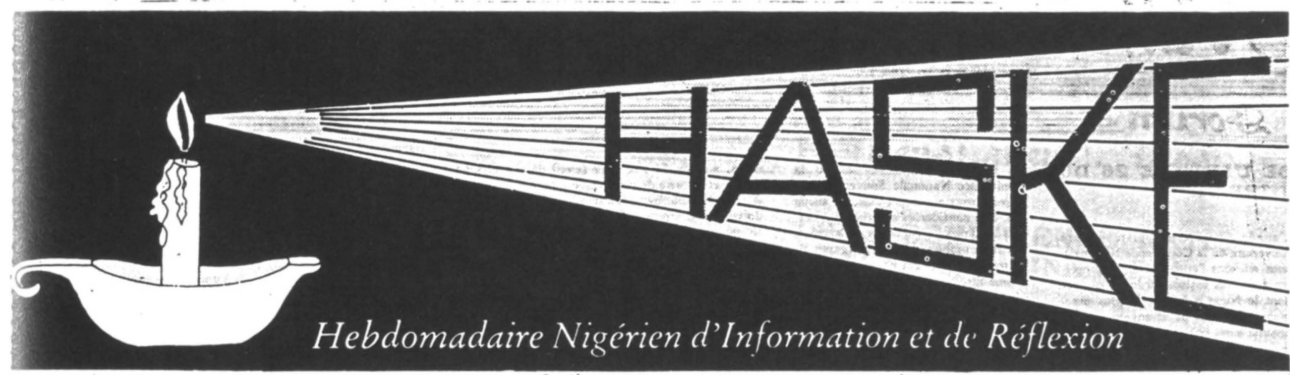

HASKE $N^{\circ} 48$ DU 9 DECEMBRE 1992 - PRIX NIGER : 300 F CFA - CEDEAO : 350 F CFA - FRANCE : 14 FF

\section{ARGDUEMT DB...CHOIX! \\ Tisait tout récemomentent disait tout récemment} (voir Haské n०46 p.8)
que les "Africains ont commis que les "Africains ont commis une erreur de raisonnement monumentale. Ils ont pensé que les colonialistes étaient des capitalistes. Le colonialisme étant détestable, ils en ont déduit que le capitalisme l'était également".

De la même maniere, on a la nette impression aujourd'hui que devant la faillite de transition, certaines personnes transition, certaines personnes sont entrain de penser que puisque cette transition était expression dun processus democratique, la démocratie $n^{n}$ 'est tout simplement pas bonne pour le Niger.

C'est avec un tel raisonnement que l'on s'apprête d nous vendre l'image du Sauveur autoritaire

Cela n'est guerre étonnant car de Platon d nos jours, en pas. sant par Mussolini et Hitler. on sait que plus un slogan politique est simple et bête. plus il mord dans l'opinion. Le niveau d'éducation n'a rien d voir dans l'affaire. Il se trouve tout simplement que Ihomme a une naturelle d la paresse : mince nanurelle d la paresse : moins on sollicite sa réflexion, plus wite il reagit. Surtout lorsque cette propagande, comme on peut le consiater ici au Niger. se fait sur fond d'ćthnicisme.

Un régime démocratique n'a certainement rien d voir avec un régime autoritaire. Et si nous connaissons bien le premier pour l'avoir subi pendant 15 ans, nous sommes encore loin d'avoir assimile les principes du second. $\mathrm{Ce}$ qui ait que dans la réalité, le choix ue l'on nous offre se resume ceci

le retour, avec des hommes Iu passé, da un système don nous subissons encore au urd'hui les ineptics.

l'aventure palpitante d'une houvelle vie qui a fait ses preuves ailleurs.

Faut-il encore hésiter?

IBRICHECK

\section{GUI VEUT DONC

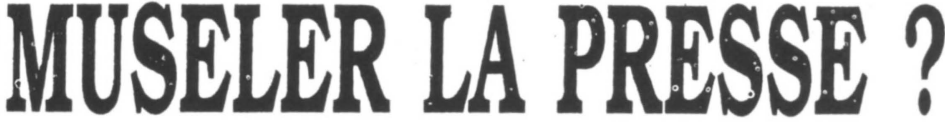

Le journal HASKE vient d'être condamné par le tribunal de Première Instance de Niamey à une peine de trois mois de prison avec sursis et 350000 F CFA d'amende pour avoir diffamé Monsieur Souley Dan Gara dit Balla Dan Sani, opérateur économique de son état. L'acte de diffamation porte sur la publication par le journal indépendant de la liste des opérateurs économiques qui, du fait de l'octroi abusif pendant la période d'exception. de licences d'importation d'essence - et cela au détriment de la Société Nigérienne de Produits Pétroliers (SONIDEP) - qui ont occasionné un manque à gagner de plus de 6 . (six) milliards de francs CFA à ladite sociêté d'Etat.

Nous avons évidemment fait appel contre ce verdict qui a tout lair d'un véritable scandale juridique. Car non seulement il n'y a pas eu, à proprement dire, diffamation, mais aussi parce que les arguments utilisés démontrent qu'on a eu droit à une véritable parodie de procès dont le verdict était connu d'avance : intimider HASKE coûte que coûte pour faire peur à toute la presse indépendante.

Décidément, les pratiques d'antan ont la vie dure !

(Notre enquête en page 4)

\section{INATILOIN}

LES VAGUES DE L'ACTE 21

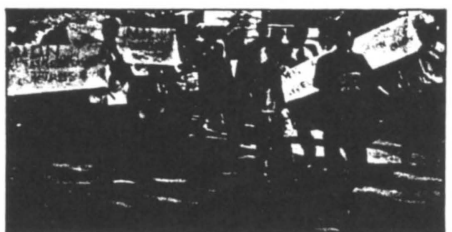

Comme prévu, la tentative de suppression a soulevé un tollé. Non sans quelques raisons...

P. 4

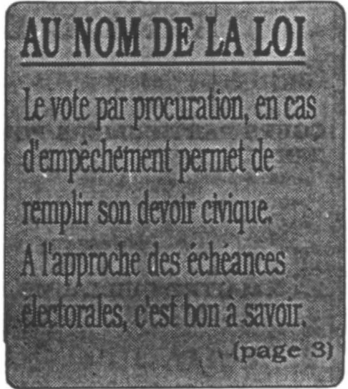

\section{SOCIETE IA CULTURE DU THEE}

Au Burkina, au Mali, au Niger, plus qu'une distraction, la consommation du thé est devenue une véritable culture.

F,TR ANGER L'INTERVENTION -AMERICAINE EN SOMALIE(p.8) 


\section{- The National Conference and the Transition period in Niger}

The National Conference of Niger started on July 29th 1991, after having been postponed twice for financial and practical reasons (Abdourahmane, 1992). The forum gathered almost one thousand delegates, lasted for 98 days and costed 400 million CFA francs (80 million French Francs $=16$ million US. $\$$ ). A lot of money and a lot of time for little results! (Raynal, 1991) The Conference degenerated almost from the very beginning into a huge "catharsis" where everybody wanted to express his personal resentment against the former regime or against particular individuals. "The Conference of all hopes has become the Conference of all dangers", wrote Haské, adding that the forum was now like "a fighting ring or a battlefield" ${ }^{12}$. Some very harmful and extremist words were pronounced and the Conference spent much more time dwelling on the past than thinking of the future. When the debates ended on November 5 th, most of the delegates were tired and disappointed. And most of the ordinary people had quit listening to the radio life broadcasting, disgusted by the permanent fightings and repetitions. Although the idea of the National Conference had been copied from the Beninese example, the copy did not match the model. And the other African countries which tried to follow that path did not do any better ${ }^{13}$.

The institutions of the democratic transition were also copied from the Beninese ones but here again, the new government accumulated mistakes and was globally unable to run the country and its catastrophic economic and social situation. On the economic level, the delegates of the students and civil servants at the Conference had refused to continue the S.A.P. any further and the country found itself without any funding from foreign institutions. The social unrest never stopped and grew even worse as the wages and scholarships could not be paid ${ }^{14}$. In the north of the country, the Tuareg community, tired of being the eternal left-outs of Niger and disappointed with the results of a National Conference where their grievances

12. Haské $\mathrm{n}^{\circ} 18$, August 26th - September 2nd 1991.

13. National Conferences took place in several countries of French-speaking Africa (Congo, Gabon, Togo, Chad, Zaïre...). None of them can be regarded as successful. (See Eboussi-Boulaga, 1993)

14. In june 1990, the transition government, paralysed by the lack of finance, announced the official recognition of the State of Taïwan (until then, Niger had diplomatic relations with Popular Republic of China). In return, Taïwan had supposedly promised $\$ 50$ million of aid for the country over the following 5 years. The first donations helped to pay the wages and scholarships, but a large part of the money had to be devoted to maintain some development projects that were until then financed by Popular China, as China broke off relations as soon as Taïwan was recognized. 
had not been heard, put their last forces into a guerrilla movement that soon set the whole northern region in fire ${ }^{15}$.

On the political level, quarrels immediately started between the new Prime Minister of the transition government, Amadou Cheiffou, and the head of the new legislative body, André Salifou. It soon appeared that for nearly all the politicians, personal interest was coming before national interest (Kotoudi, 1993). Among the military, there was a lot of resentment as the army had been rejected from the political stage and had therefore lost its numerous privileges. Two mutinies occurred, each time directly threatening the democratic process. In August, the troops arrested some 200 important Tuaregs, without having received any order to do so. They kept these civilians in prison until February 1992 and the transition government didn't make any effort to put an end to this illegal situation ${ }^{16}$.

That chaotic transition period was also the time when islamic fundamentalists started violent riots in Eastern Niger and when clashes between nomadic shepherds and sedentary farmers caused dozens of deaths. Eventually, when the transition period came to an end in Niger, everybody felt releaved. "The end at last! That transition seemed endless... and even the most patient ones ended up being discouraged"17, wrote the newspaper Haské for which the transition had been "a long walk through the desert guided by ruthlessly ambitious politicians" ${ }^{18}$.

The democratic polls were probably the major successes of the transition period. The new Constitution was adopted through referendum in December 92, and the parliamentary and presidential elections took place in February and March 1993.

15. The Tuaregs are a people of nomadic shepherds living in the Sahel and Sahara. They have always been left out, even rejected, by the Nigerien state. In 1973 and 1984, two severe droughts killed most of the flocks, reducing the Tuareg people to extreme poverty and forcing them to settle down in villages. Most of the foreign aid that was supposed to support the Tuaregs through that catastrophe was embezzled by political executives, creating a lot of frustration among the population.

16. The situation was not only illegal but also absurd as, among the prisoners, there were many officials and even one Minister, member of the transition government. A governement that has just ignored the fact that a minister was missing... until the day he was released!

17. Haské, Special issue, February 12th 1993.

18. Haské, n60, March 19th 1993. 
Mahamane Ousmane became the first democratically elected President in the history of Niger ${ }^{19}$.

Another positive and durable change in the Nigerien transition period is to be found among the media. During that period, private newspapers multiplied: just before the National Conference, Le Républicain had joined Haské in his fight for democratic changes. Then Anfani, Le Démocrate, Le Paon Africain, Moustique... appeared. There were not as many newspapers in Niger as in Benin during the similar period. Several reasons stand for that: firstly, Niger is a landlocked country where it is very difficult to find all the equipment and raw materials necessary to produce a newspaper ; this puts the cost of the newspaper production very high. Secondly, Niger is a poor Sahelian country where most people can not afford buying the paper, especially if it is comparatively expensive. Thirdly, for historical reasons mainly going back to colonisation, the literacy rate is lower in Niger that it is in Benin (12\% for $25 \%$ ).

But even if they have a relatively small circulation, the Nigerien newspapers still played a part in the democratic transition. They initiated a new type of journalism that had never been practised in that country before. They probably influenced the journalists working in government media which opened up progressively. There was an obvious change in the way "La Voix du Sahel" and "Télé-Sahel" handled reporting during the National Conference and along the transition period. The media broadcasted interviews and debates with the different political parties and trade-unions, reflecting the emerging pluralism. During the transition period the source of authority and power is not unique anymore, but plural and less clearly defined. The national media were not fearful because they did not really know who and what they should fear. They were freed from their constant submission as they did not know exactly who was (nor who would later be) in charge of public affairs. And that is why, in Niger also, when a new President was elected, things changed: attempts from the government to control state-owned media revived and the journalists felt again the weight of the authority to which they belonged.

19. He was also the first president belonging to the Haussa ethnic group which is majoritary (55\%) in Niger. Since colonisation time, the political structure, the army and most of the civil service had been dominated by the Zarma (22\%). The victory of Mahamane Ousmane thus also meant "ethnic change" at the top of the country. 


\section{- The post-transition period}

If the democratic transition period in Niger can be judged as a failure, the worse was yet to come. The new democratically elected President, Mahamane Ousmane, rapidly showed authoritarian tendencies and quarrelled with the political parties from his coalition first, then with the National Assembly and eventually with his Prime Minister who resigned in October 1994. For months, the State apparatus was paralysed until the Assembly was dissolved and anticipated legislative elections were held in January 1995. The former State-Party, the MNSD, won the election and imposed to Mahamane Ousmane a Prime Minister of its choice, Hama Amadou. The State remained paralysed for one year as the President and the Prime Minister refused very quickly to collaborate. Eventually, on January 29th 1996, a military junta made a coup bringing the General Ibrahim Baré Maïnassara to power. It was the first coup d'etat in French-speaking Africa since the democratisation process began in 1990.

Although he first said he would give back the power to civilians, Baré Maïnassara decided to be candidate for the presidential election held on July 7th and 8th 1996. He won at the first round but the election was contested by civilian democratic forces $^{20}$ (political parties, labour unions and some private newspapers) accusing Baré Maïnassara of having stagged an "electoral coup d'état" ${ }^{\text {"21 }}$. After the January coup, Baré's attitude towards the press was harsh as he tried to establish censorship and intimidated the editors and journalists. It didn't prevent some newspapers from criticizing very sharply the newly elected President. The future of the private press, as the one of the whole country, remains until now very uncertain.

\footnotetext{
20. The presidential election ended in confusion : the Independent National Electoral Commission (CENI) was disbanded on July 8th, three hours before the closure of the polling. The security forces collected a certain number of ballot boxes and records. The homes of the candidates were placed under surveillance (Africa Research Bulletin, vol.33, $\mathrm{n}^{\circ} 7$, July 1st-31st 1996, p.12337-12338). The election was also condemned by foreign nations including the United States that suspended its economic and military aid programme to Niger "in reaction to the obvious adandonment of democracy".
}

21. Alternative, $n^{\circ} 81$, August 23rd 1996. 


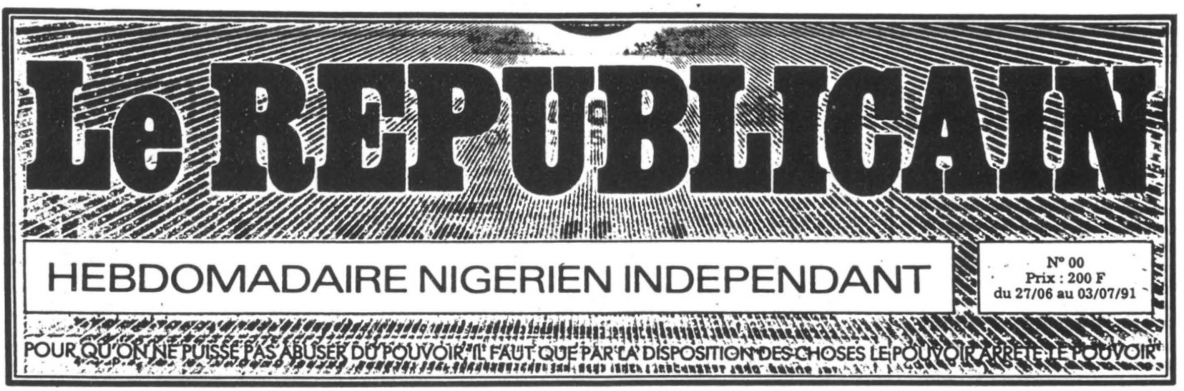

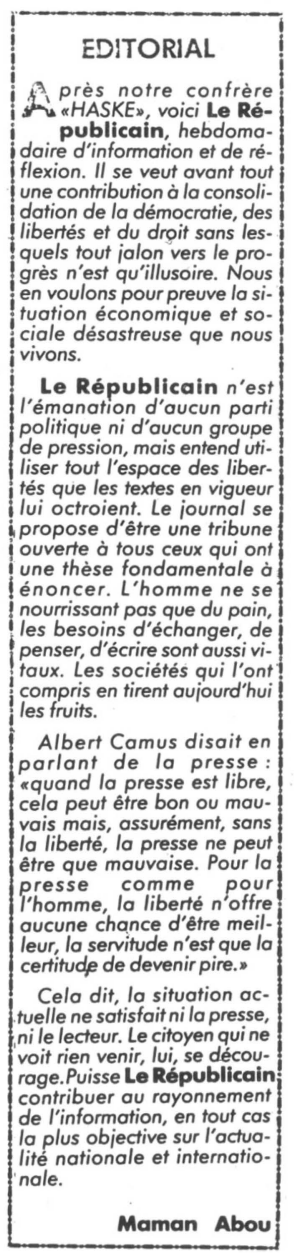

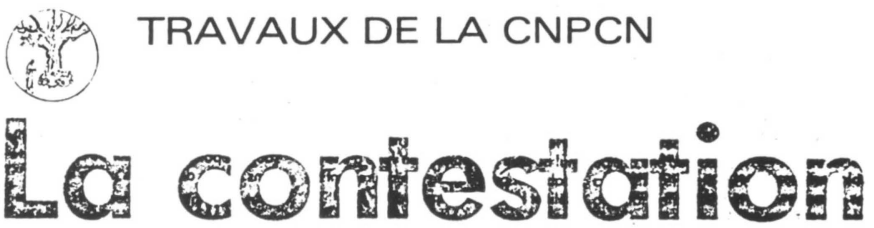

L'INCERTITUDE PLANE SUR LA CONFERENCE NATIONALE

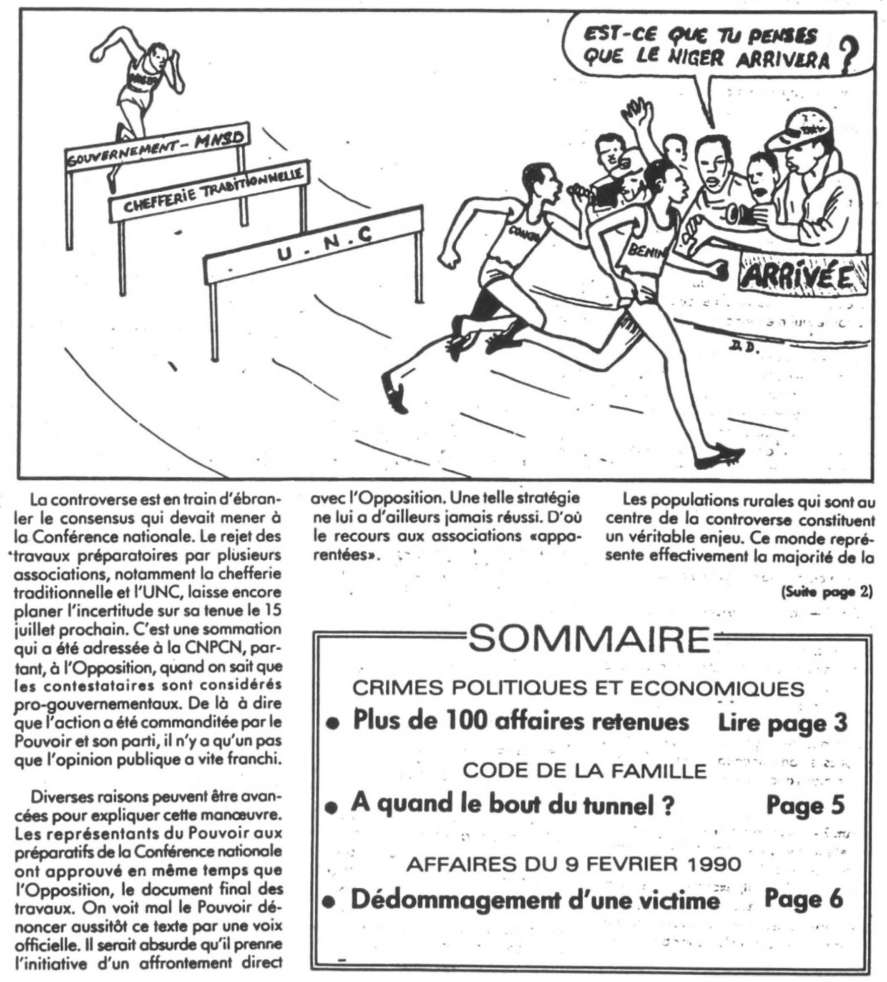




\section{Media and Democratic Transition}

The description of the democratic experiments in Benin and Niger shows that there is no such thing as a "democratic transition model" which would be valid everywhere and for every country. The National Conference, viewed as a "Beninese invention" had poor results when it was transplanted in the neighbouring countries. Nevertheless, if there is no institutional model, there are some main factors that can be regarded as necessary for the implementation of democracy. Most of the political scientists writing on democratic processes acknowledge the fact that the emergence of a private press, freely voicing the opinion of different people or groups of people is "an important priority" for complete and durable democratization of any society (Diamond, Linz, Lipset, 1990). In Niger as in Benin that priority has probably been fulfilled, although partially. We will now give a closer look to that new, private, written press and its role during the democratic transition.

\section{- The different roles of the private press}

The role of the journalist completely changed as the new private press emerged during the process of democratization in French-speaking West Africa. The journalist is not a tool in the hands of the rulers anymore, serving as their mouthpiece: he has become an independent actor on the political stage. The new private press is now a critical observer of the political field at the same time as a watchdog for the good of the democratic transition. In that sense, it can be said that it acts as "opposition forces" in order to control the people in power. One of the favourite subjects of the papers during the transition was the denunciation of all abuses committed by the former (and sometimes the new) government. As the editor of a Nigerien paper said: "The press might not be strong enough to prevent our leaders from making personal profit or breaking the law, but at least it is dissuasive. They know that if they do so, the whole country will be aware of it. And all depends then on the capacity of the civilians to take action about it once they know. That is beyond the ability of the press." ${ }^{22}$

The involvement of the press in the political field is also obvious during the several votes. During the presidential election in Benin, almost all newspapers overtly called the people to vote for Nicéphore Soglo. La Gazette du Golfe wrote that

22. Bori Seyni, Le Démocrate (Interview, Niamey, May 1994). 
people should obviously give their favour to Soglo asking whether there is "anyone who would prefer slavery to liberty"23. In Niger where the private press was split between supporters of the candidate of the former "parti unique" and the one of the "forces for change", the latter for example wrote: "The victory of Ousmane is the victory of democracy" (Haské) ${ }^{24}$ and "Le Paon incites you to vote for Mahamane Ousmane"25. In both countries, the new private press stated their opinion clearly on the main political issues during the transition period. In that sense too, it claimed to be an actor of the democratic process.

Nevertheless, regarding the role of the private press in democratic transitions in West Africa, one may notice that the new private press can also often be a means to legitimate the people in power. It is a visible, concrete sign of freedom that often serves as a "democratic façade" for regimes willing to please foreign standards of good governance. That was the case in Benin and Niger before the National Conferences, and it was obvious in countries like Ivory Coast or Mauritania where freedom of the press was granted but there was obviously no will on the part of the leaders to give a chance to political alternance. At this point, the press plays an ambiguous part: for while it criticizes the government, denounces abuses or claims for deeper reforms, the free press is the best tool for the government to show that democracy is effective in the country and to avoid external pression for even deeper changes.

\section{- A linguistic renewal}

The difference between the new private press and the former official newspapers is not only one of the place occupied or not, active or not on the political field ; it is also a question of language. The discourse and the tone of the journalists have completely changed. Before the democratic transition, the Beninese and Nigerien press wrote in a very rigid, ceremonious style and the press was supporting an official ideology always presented as the universal Truth (be it marxism-leninism in Kérékou's Benin or the Nigerien concept of "Development Society" invented by late President Seyni Kountché). The new private press definitely turns its back to that conception.

23. La Gazette du Golfe n69, March 16th-31st 1991.

24. Haské nº1, March 19th 1993.

25. Le Paon Africain, $\mathrm{n}^{\circ} 20$, March 9th 1993. 
Firstly, it is obvious now that there is no such thing as a "universal" or "national" Truth, but a variety of personal beliefs and opinions. And the opinion of the person who happens to be the President of the country is not worth more than anyone else's belief. It can therefore be criticized or contradicted.

Secondly, new concepts appear constantly in the press and are often discussed by the journalists or in the readers column: "democracy", "multiparty-system", "freedom of speech", "human rights", "elected representative"... Both Beninese and Nigerien newspapers discuss the following issues openly: What are the minimal conditions for a regime to be called "democracy" ? What is the best electoral system ? Should there be limitations to freedom of speech ? Should the number of political parties be limited? When does a people have the right to rebel against its elected leaders?

Thirdly, the new private press expresses its convictions and opinions in a totally "renovated" or "liberated" language. Irony, slang, insults, metaphors, scorn have become usual in these newspapers where caricatures are most common. In Benin, Kérékou is referred to as the "Chameleon"26, Soglo was called "Father Christmas" as he was distributing food and presents to the peasants during his electoral campaign. Mahamane Ousmane's nickname in Niger soon became "Emperor Nafarko"27 and former President Ali Saibou was a "Sweet Granddad". That "verbal creativity" deeply renews the political discourse people are used to in West Africa ${ }^{28}$.

Those new language practices also destroy the sacred aura usually surrounding the political leaders. Irony towards the "Big Men" existed before but was hidden:

26. That nickname couldn't be more appropriate than now : Mathieu Kérékou, the symbol of 17 years of military marxist-leninist dictatorship in Benin has just been elected President in March 1996, after free and fair elections. The incumbent President Nicéphore Soglo has not yet overcome his defeat.

27. "Nafarko" means "first" in Haussa language. That nickname was given to President Ousmane because he was constantly referring proudly to himself as "the first President democratically elected in the history of Niger". (The Haussa ethnic group is majoritory in Niger and in many places like the capital-city Niamey, Haussa is the vernacular language.)

28. Research on the African press also show that some features specific to oral tradition (such as redundancy, imagery, aggregative rather than analytic thinking...) appear in that press (Bourgault, 1995). 
for example in double-faced popular songs (Toulabor, 1991) ${ }^{29}$ or in clandestine papers (La Flamme in Benin). It was also carried by "radio-trottoir" (for which the closest English translation could be "bush telegraph"). All that informal political information is now openly written or shouted publically, in a sometimes excessive manner. Indeed, many newspapers have happened to fall from irony to insult, from criticism to defamation. It is probably unavoidable when freedom of speech comes back to the ones that have been deprived from it for decades ${ }^{30}$.

History also shows that political revolutions are often going hand in hand with "linguistic revolutions". Research on the French Revolution have shown that the 1789 events were not only important on a political ground, but also constituted a "language experiment". More than a hundred newspapers appeared in Paris in a few months, defending new political ideas and concepts, experiencing a real "explosion of free speech" (Labrosse and Retat, 1989) ${ }^{31}$. The "democratic revolution" in West Africa probably could not come without a "political language revolution".

\section{- The limited impact of the press}

The democratic transition has thus brought (and at the same time was built on) a new conception of journalistic practise, new roles for the press and a new type of political language. Nevertheless, the press encounters important limitations, restricting its audience enormously and thus its impact.

The first limit is due to language. All the private newspapers in Benin and Niger are published in French. In both countries, French remained the official language

29. This author shows how, in Togo, some popular songs were actually hiding strong criticism against President Eyadema's regime.

30. In two years (1991-1992), there has been not less than 50 trials for defamation or libel in Benin, most of them involving the new private press were lost by the newspapers.

31. Of course, this type of comparison between African democratic transition and the French Revolution can only be limited, as the historical, social, economical and political contexts are profoundly different. Nevertheless, it's important to mention that comparison was made by the new private press itself in Benin as well as in Niger. We should remember that the editors of most of these newspapers started school either under colonial rule, either just after Independence, when school programs were still directly copied from France and the French Revolution, the Enlightment, the Declaration of Human Rights were of course part of the syllabus. 
after the Independence for practical as well as political reasons. In fact, both countries are multilingual and the choice of one of the local tongues as official language would have been considered as the affirmation of the supremacy of that particular ethnic group. But the literacy rates are very low (about $12 \%$ in Niger and $25 \%$ in Benin) which is a big restriction for the written press ${ }^{32}$.

A second limit is financial: most people cannot afford to buy a newspaper regularly. Each paper that is sold passes from hand to hand and is probably read by ten people or more, but the publisher only gets the money once. Some of the youngsters selling the newspapers on the streets also "rent" the copies to customers: for 20 or 50 CFA Francs, you can borrow the paper you wish for half an hour. Therefore, most of the newspapers have a very low circulation. During the transition period, especially around National Conferences, peaks were reached with circulations going up to 20.000 in Benin and 15.000 in Niger, but it soon went down to 5.000 or 3.000. Many newspapers were then pushed toward sensational reporting in order to gain readers and the new private press filled itself with rumours and gossips ${ }^{33}$. That led to an increasing number of defamation trials and the press lost a lot of its credibility. The difficult financial situation also led the editors and the ill-paid journalists to accept the financial backing of political parties or leaders, bringing the new press to much biased and unfair reporting sometimes close to propaganda. Many readers turned their backs to the press because of this type of behaviour.

Geography puts a third limit to the impact of the written press. All newspapers in both countries are published in the capital city and hardly go beyond. Especially in Niger which is a huge country where transportation is difficult: the newspapers cannot be sent in more than six or seven main towns and usually reach them many days late. In Niamey as in Cotonou, the editors are also reluctant to send too many copies out of the capital: firstly because one has to go every week to the bus station, try to find a driver ready to take the copies and bargain for the trans-

32. Illiteracy is no obstacle for radio. But in Niger and in Benin there is as yet no private radio station able to reach the huge majority of illiterate peasants. In Niamey (Niger), two private stations were created (R\&M and Radio Anfani), both of them on MF and mostly musical. In Benin, it's only in December 1995 that a first private radio station (Golfe Radio) was allowed to run trials in Cotonou. Meanwhile, two international Frenchspeaking stations, Radio France Internationale and Africa $n^{\circ} 1$, were allowed to start broadcasting in both countries. It's obvious that in Benin, as in Niger, the radio field is the one the new leaders want absolute control on.

33. Revelations about the private life of politicians, news items about sorcery and magic, found more and more space in the newspapers. But the "extraordinary" headlines seldom matched with the content of the paper with usually very insignificant information. 
portation. Secondly, most editors know that when they send copies to other towns, they will never get the money of the sales. The people playing newsagents do not bother to send back the profits of the sales, which is also difficult as there is hardly any banking system out of the capital city.

A fourth limit is to be found in the strong integration of the newspapers in the political field. In fact, journalists and political activists belong to the same community: the French-speaking urban elite, mostly composed of teachers, civil-servants and students. We have explained in the first part of this paper how that part of the population had been the one claiming for democratic changes, the one attending the National Conference and the one involved in setting up new political parties. Journalists and political activists belong to the same new (more or less, or not at all) ruling class: they have many common points, common interest and common aims ${ }^{34}$. That is partly why most of the reports concern political current events. The private press is often a matter of an elite writing for an elite on what the same elite is doing. The problems met by peasants and poor suburban people ( 80 to $85 \%$ of the population) are quickly reviewed or ignored by the newspapers. In Niger for example, there was a severe drought during the transition and about 2.000 villages were threatened by starvation: none of the newspapers made extensive reports on that tragic situation and some of them did not even mention it.

From those four limits, we can conclude that even if the press is free, it is not the spot of national reconciliation: it is still monopolised by a minority and it excludes the majority.

\section{- The limited extension of Democracy}

We have mentioned four limits met by the new private press in the democratic transition in Benin and Niger. In fact, it seems that the same factors also limit the democratic implementation itself.

There is a "geographical" limit to the new-born Nigerien and Beninese democracies as peasants from the countryside, who are largely dominant, seem to be left out of the process. The early demonstrations, the National Conferences (where peasantry

34. And, in fact, many newspapers are more or less financed by political parties. In a way, it's unavoidable, given the difficult financial situation : advertisement hardly exists while the political parties are always ready to pay for a paper to flatter them. It's also due to the fact that journalists belong to the same social class as the political elite. 
was under-represented ${ }^{35}$ ), the transition and the new democratic institutions were and still are more meaningful for the urban elites than for the rural or suburban population. About the composition of the new Beninese National Assembly, the Beninese newspaper Le Forum de la Semaine notices: "Professors and senior executives occupy 52 seats out of 64 . If you add the lawyers, they reach 57 seats. (...) Notably absent from the Assembly are the peasants. There are no peasants at all. (...) And on the 64 deputies, 44 actually live in Cotonou and 7 in Porto$\mathrm{Novo}^{36}$. Beninese deputies are thus part of the urban elite." 37

Rural people are often viewed as "second class" citizens and no one cares about their political opinion. The old and new politicians just bother to go back to the village during electoral campaigns to distribute money and presents in order to gain votes. They make many promises, then go back to the city and forget all about them. And the figures from the polls show that "anyway, the rural people always vote for "the son of the village". 38 "(Syfia, 1995) The political parties tend therefore to use regionalistic, ethnic, if not tribal propaganda to gain supporters and do not care about setting up real programs. In Niger, Anfani denounced the "abusive use of ethnicity, regionalism, and even Islam to serve political aims during the electoral campaigns." ${ }^{39}$ And in Benin, Tam-Tam Express fears that multi-partyism is about to "awaken the old devils of regionalism which threaten the national unity dangerously. ${ }^{40}$

There is also a "financial" limitation to the democratic process. There has been much debate about the relation between the wealth of a country and its tendency

35. In both countries, there was much discussion and argument about the quota of delegates from each association. There has been a conscious attempt on the part of the urban educated elite to limit the number of peasant participants as these were considered as "traditional" and "conservative", that is to say in favour of the old regime.

36. Cotonou is the economic capital but Porto-Novo remains the administrative capital city. Both are on the coast (Southern Benin) and only $40 \mathrm{~km}$ apart.

\section{Le Forum de la Semaine ${ }^{\circ} 52$, April 10th-16th $1991 .$.}

38. The results of the 1993 elections in Niger show very strong "ethnic" solidarity. It's particularly obvious as the democratic "proportional" system has brought an ethnic change at the top of the state apparatus. In Benin, at the 1991 presidential election, the four top candidates had obviously gathered votes in their region of origin : Kérékou in the North, Soglo in the Zou, Tevoedjre in the Ouémé and Amoussou in the Mono.

39. Anfani $\mathrm{n}^{\circ} 14$, February 16th-28th 1993.

40. Tam-Tam Express n60, March 18th-31st 1991. 
to democracy, about the link between development and political pluralism and we will not discuss that issue again ${ }^{41}$. But it is obvious that democracy cannot be easily implemented in countries where people are only anxious about daily survival. In addition, new-born democracies in Benin and Niger develop in surroundings where, for many years, the state and its apparatus has been the best tool for quick and easy personal enrichment. That has been referred to by the French political analyst Bayart as "the politics of the belly" (Bayart, 1989): as soon as one has managed to reach a post in the administration, one just "eats" as much as one can. This concept is completed by Médard's "neo-patrimonialism" which qualifies the way African political leaders have always taken the national public property as their personal belongings (Médard,1991). These habits did not disappear with the democratic transition as the rise of political pluralism in those poor and under-developed countries has awakened new ambitions and new opportunities for career and enrichment. "Many have already found how to use "democracy" to make profits", notices the Beninese newspaper Tam-Tam Express ${ }^{42}$. And, in Niger, Le Démocrate writes: "The elites that were excluded from the old privileged system (...) are now using democracy in order to get their share of the national cake." 43

The problem of the language can be enlarged to the problem of "culture" in general and specifically "political culture". One can define the "political culture" as the particular filter through which the people look at, perceive and interpret relations of domination, political acts and facts (Martin, 1991). With the democratic transition, we have mentioned that new concepts appeared as well as new institutions. Nevertheless, it is not just because new institutions such as parliament, political parties and free press are set up that the general political culture changes. For democracy to take root in a country, there should be a basic commitment to democratic principles and ideals. And so far, it is not sure that such a commitment does exist, neither among the rural and suburban population that's left out of the process, neither among the leaders.

Le Forum de la Semaine writes: "80\% of the Beninese people do not understand the scholarly explanations they are given about democracy. They are anxiously wondering what those intellectuals are preparing for them now that their marxist-

41. For contrasted recent analysis, see Ake (1996) and Kabou (1992).

42. Tam-Tam Express ${ }^{\circ} 50$, October 20th-November 2nd 1990.

43. Le Démocrate, n³1, December 21st 1992. 
revolution is over." ${ }^{44}$ The democratic renewal in Niger and Benin brought Constitutions and institutions that were copied from the French ones. They therefore ignore some of the fundamental principles that remain relevant to the local population. The Nigerien newspaper Haské writes: "That type of democracy that is settling in Africa is far from satisfying the ideals of African populations." 45 And in Benin L'Opinion writes: "We should build our political structure on the basis of our own experiments. "46 Therefore, a Beninese or Nigerien "democratic culture" should not deny some factors that are deeply rooted in the mentality: factors like ethnic or regional belonging, religion and witchcraft, specific ways of gathering and redistributing the wealth... are the ones to which the majority of the people relate, including the leaders (Copans, 1992).

But how could such an endogenous democratic culture be built ? It does not seem that the political elite is ready to work on that point and to help implement democratic principles in the countryside by adjusting "French" values to traditional ones. In fact, as we have mentioned, the commitment of the ruling elite to democratic principles is not at all certain. Of course the French-speaking Westerneducated elite is able to manipulate the "democratic vocabulary" and thus occupy the democratic institutions, but some of their behaviour seems to be totally opposed to democratic principles. Some politicians do not hesitate to revive ethnic hatred. Many of them tried to corrupt the electorate. And corruption and "politics of the belly" is far from having disappeared.

Could the newspapers help to build a new "democratic culture" ? Maybe. As we have seen above, the private press is the first to notice all the failures and manipulations of the rulers. Even if the impact is limited, the voice of the journalist actually exists. And if they can not prevent the democratic transition to be built while leaving aside most of the people, maybe they can at least remind the leaders about the existence and problems of the outcasts. They can remind the leaders that their power is limited and that the democratic process is something one has to work on continuously because it is never achieved.

44. Le Forum de la Semaine ${ }^{\circ} 23$, September 19th-25th 1990.

45. Haské $\mathrm{n}^{\circ 34}$, April 29th-May 6th 1992.

46. L'Opinion $\mathrm{n}^{\circ} 7$, June 22nd-July 6th 1990. 


\section{Conclusion}

Press pluralism and political pluralism appeared almost at the same time in West African countries going through democratic transition. Newspapers and political parties multiplied between National Conferences and the first democratic election. In Benin, about 40 newspapers and 30 political parties were created during the transition period while in Niger 15 newspapers and 25 parties were born. Most of the urban French-speaking elite then supported the press and got involved in political groups.

But that time of hope and enthusiasm was followed by disappointment. Many civil-servants, students, who had been demonstrating during the early political awakening and had filled the reader's columns in the new private press became embittered. They realized that democratic transition had not brought along immediate change in their daily life, they noticed that most of the new political leaders had authoritarian tendencies or were merely searching for personal enrichment, they understood that the so-called "democrats" all had more or less strong links with the former regimes. They also turned away from a private press that had gradually become more "sensational" and was on the pay roll of political parties.

In Europe, democracy has been developing, with ups and downs over the past two centuries. Obviously, it could not be perfect after only a couple of years in West Africa. The way to democracy is "a long painful process of learning"47, writes La Gazette du Golfe. It is therefore quite understandable that the people, who hoped that the new-born democracy would bring an immediate answer to all their problems, should now be disappointed. But that disappointment should not bring the people to doubt about the legitimacy of the democratic process itself. The Nigerien newspaper Haské wrote: "In front of the failure of the transition period, some people are about to think that since that transition was the expression of a democratic process, then democracy is not good for Niger. With that type of reasoning, we'll soon be ready to be ready for the return of the "authoritarian saviour".48

Currently, Benin and Niger are both at a turning point of their democratic process. In Benin, the former communist military dictator Mathieu Kérékou has won the presidential election in March 1996. In Niger, on January 29th 1996, a military coup overthrew the democratic rulers that had been quarrelling one another for

47. La Gazette du Golfe ${ }^{\circ} 57$.

48. Haské n 48, December 9th 1992. 
the last two years, paralysing the state apparatus. The new head of state, General Ibrahim Baré Maïnassara, was elected President during contested elections last July. Is it, in both countries, the actual "return of the authoritarian saviour" that Haské had predicted ? After "democratisation", should we talk of "restoration"?

Ibrahim Baré Maïnassara, congratulating Mathieu Kérékou after his victory in presidential election, said that it again showed "disillusion with this democratisation in which people have placed so much hope, particularly in West Africa". The Nigerien evolution just reminds us that there is a very easy replacement solution to cope with the difficulties of inventing African style democracy. And the events in Benin prove how politics remain within the hands of the same dominant elite mainly concerned by personal career and enrichment. The new government appointed by Kérékou is composed mostly of former political rivals who only got together to fight Soglo. The lack of cohesion of the team and its inefficiency are already provoking much anxiety.

Nevertheless, some of the principles or benefits of the democratic process seem to be deeply rooted in both countries. The private press is among those gains: the journalists want to believe that never again they will stand as "muffled drums"49 (Hachten, 1971). Even though the number of newspapers has decreased (except during election periods when new papers always multiply), even though the ones that remain have a poor circulation and a sometimes appalling content, the private African press is still an actor of the democratic implementation. And its main quality, in a very unfavourable context, probably remains... its existence!

\section{BIBLIOGRAPHY}

- ABDOURAHMANE Soli (1992), Conférence Nationale du Niger, Niamey, Imprimerie Bankoukou.

- ADAMON Afize (1995), Le Renouveau démocratique au Bénin: la Conférence Nationale des Forces Vives et la période de transition, Paris, L'Harmattan.

- AINSLIE Rosalynde (1966), The Press in Africa: Communication Past and Present, London, Voctor Gallacz Ltd.

49. Political change in neighbouring Nigeria worries both Beninese and Nigerien journalists as it shows that even in a country where the freedom of the press has been a long time habit, the journalists are not safe from reversal of threats and control. 
- AKE Claude (1996), Democracy and Development in Africa, Washington DC, Brookings Institution.

- ALLEN Chris (1992), "Restructuring an Authoritarian State: Democratic Renewal in Benin", in Review of African Political Economy, n ${ }^{\circ 54, p .42-58 .}$

- ASSEVI Akuété (1993) "La situation politique, les changements récents et la démocratisation au Bénin", in CBC/SRC, Le Journalisme en démocratie,p.7-22.

- BARTON Frank (1979), The Press of Africa: Persecution and Perseverance, London, Macmillan Press.

- BAYART Jean-François (1989), L'Etat en Afrique: la politique du ventre, Paris, Fayard.

- BOURGAULT Louise (1995), Mass-Media in Sub-Saharan Africa, Bloomington, Indiana University Press.

- COPANS Jean (1992), La longue marche de la modernité africaine, Paris, Karthala.

- DIAMOND Larry, LINZ Juan, LIPSET Seymour Martin, (1988) Democracy in Developing Countries. Vol.II. Africa, Boulder, Lynne Rienner Publishers.

- EBOUSSI-BOULAGA Fabien (1993), Les Conférences Nationales en Afrique Noire: une affaire à suivre, Paris, Karthala.

- GBADO Béatrice (1992), En marche vers la liberté, Porto-Novo, CNPMS.

- HACHTEN William (1971), Muffled Drums: The News Media in Africa, Ames, Iowa University Press.

- HEILBRUNN John (1993), "Social Origins of National Conferences in Benin and Togo", in The Journal of Modern African Studies, n³1, p.277-299.

- IBRAHIM Jibrin (1992), "From Political Exclusion to Popular Participation: Democratic Transition in Niger Republic", in CARON, GBOYEGA \& OSAGHAE (Ed), Democratic Transition in Africa, Ibadan, Credu.

- KABOU Axelle (1991), Et si l'Afrique refusait le développement ?, Paris, L'Harmattan.

- KOTOUDI Idimama (1993), Transition à la nigérienne, Niamey, Nouvelle Imprimerie du Niger.

- LABROSSE Claude \& RETAT Pierrre (1989), Naissance du journal révolutionnaire: 1789, Lyon, Presses Universitaires de Lyon. 
- LAKE René (1993), "Niger: le pluralisme radiophonique", in PANOS-UJAO (Ed), Le Pluralisme radiophonique en Afrique de l'Ouest, Paris, L'Harmattan.

- MARTIN Denis-Constant (1991), "Les cultures politiques", in COULON \&MARTIN (Ed), Les Afriques politiques, Paris, La Découverte, p.157-171.

- MEDARD Jean-François (1991), "L'Etat néo-patrimonial", in MEDARD (Ed), Etats d'Afrique Noire: formations, mécanismes, crises, Paris, Karthala.

- QUENUM Ephrem (1990) "Bénin: l'explosion d'une presse privée et d'un ton nouveau à la radio-télévision", in Multiplex $\mathrm{n}^{\circ} 44$.

- RAYNAL Jean-Jacques (1991), "La Deuxième République du Niger", in Penant, p.380385.

- RAYNAL Jean-Jacques (1991), "Le renouveau démocratique béninois: modèle ou mirage?", in Afrique Contemporaine n ${ }^{\circ} 160$, p.3-26.

- RAYNAL Jean-Jacques (1993), Les Institutions politiques du Niger, Saint-Maur, Sepia.

- RAYNAUT Claude, "Trente ans d'indépendance: repères et tendances", in Le Niger:

Chroniques d'un Etat, Politique Africaine, ${ }^{\circ} 38$, p.3-29.

- SYFIA (Ed) (1995), Feux de brousse: l'aventure de la démocratie dans les campagnes africaines, Paris, Syros.

- TOULABOR Comi (1991), "La dérision politique en liberté à Lomé", in Politique Africaine, $\mathrm{n}^{\circ} 43, \mathrm{p} .136-141$.

- VITTIN Théophile (1991), "Bénin: du "système Kérékou" au Renouveau Démocratique", in MEDARD Jean-François, Etats d'Afrique Noire: formations, mécanismes et crises, Paris, Karthala.

- VITTIN Théophile (1992), "Crise, renouveau démocratique et mutations du paysage médiatique au Bénin", in Afrique 2.000, n9, p.37-57.

- ZIEGLER Dhyana \& ASANTE Molefi K. (1992), Thunder and Silence: The Mass Media in Africa, Trenton (N.J.),Africa World Press Inc.

\section{NOTE}

This paper is based on a Ph.D. research supported by the Belgian National Fund for Scientific Research. I'm grateful to Mireille Lebrun, Alain Lorfèvre and Carine Demousselle for their advice and help for the translation. 